\title{
The Effect of the Learning Process on the Increasing of the Level of Understanding of the Student on State Ideological Issues
}

\author{
B Haryono \\ Department of Sociology, Faculty of Social and Political Sciences \\ Universitas Sebelas Maret \\ Surakarta, Indonesia \\ bagusharyono@staff.uns.ac.id
}

\begin{abstract}
The strength of globalization has impact on the decreasing of the level of understanding of the student on the State Ideological issues. The objective of this research is the sociology student at Universitas Sebelas Maret. The aim of research is to explain the influence of the Learning Process (LP) on the level of the understanding of the student on the State Ideological (LUSSI) issues. It designed by quasi-experimental, conducted by pre-test, treatment and post-test. Data were collected by questionnaires. Respondent comprised of class B of the sociology graduate student attending at the major of The Sociology of Education (SEdu) in the semester 2016/2017. The LP given by the treatment by focusing the any topic of the SEdu subject matter on the political education (the culture values: Pancasila Ideology and Bhinneka Tunggal Ika) and the structure (the 1945 Indonesia Constitution and United State of Republic of Indonesia). Findings showed that the LP has positive effect, as indicated by significant increase in the LUSSI score in the posttest more than the pretest.
\end{abstract}

Keywords-effect; ideological; treatment; understanding

\section{INTRODUCTION}

The Indonesia peoples are aware that pragmatism and materialism [1,2] have penetrated throughout their life [3,4], certainly it has a very negative influence toward the Indonesian young generation. But they are still firmly upholding the ideology that strengthens the four pillars of national and state life. The Surakarta peoples understood and actualized the four nation pillars: Pancasila, the 1945 Constitution, Unity in Diversity (Bhinneka Tunggal Ika), The Unity State Republic of Indonesia [5,6,7] in mural [3]. The State Ideological issues in this article specifically focusing on the political education issues [8]. The first issue related to the culture values [9]: Pancasila Ideology and Unity in Diversity. The subject matter is given in the discipline of Sociology of Education [10], Indonesian Political System, Political Sociology, Citizenship, Socio-Cultural System of Indonesia and Pancasila. The second issue related to the structure (the 1945 Indonesia Constitution and United State of Republic of Indonesia). The subject matter is given in the course of Indonesian Law System, Sociology of Law, Sociology of Education [11]
The Behaviorism said that learning theories undertaken by the teachers to the students through the stimulus-response mechanism, in which teachers provide stimulus, students respond. In the Gestalt theory, learning theories that adhere to teaching should be holistic, whole of the parts that are mutually influential or dependent. The cognitivism introduce the learning theory by emphasizes the importance of the subject in the learning process. The Active Student's Learning, represent the learning theory that emphasizes the importance of psychological mental involvement students in the whole process of teaching and learning. Contextual Teaching and Learning, focus on the learning theories that emphasize the importance of teaching and learning contextually, explaining it in context. The thematic-Integrative Approach, focus on the learning theory that emphasizes the importance of teaching and learning on a particular theme or sub-theme, and integrating it with other learning materials. Communicative approach, focus on the learning theory that emphasizes the importance of the subject's ability to communicate ideas, and others can understand it. A collaborative learning emphasizes the importance of teaching and learning to enhance learner's performance [12]. Learning Process, as the all of the overall activities related to the transformation process from the prior understanding and directed toward intended understanding. Bloom said that the learner should benefit from development of knowledge and intellect (cognitive domain); attitude and beliefs (affective domain); and the ability to put physical and bodily skills into effect - to act (psychomotor domain) [13]. The cognitive domain covered six levels. Level 1 or category (Knowledge); behaviour descriptions (recall or recognise information); examples of activity to be trained, or demonstration and evidence to be measured (multiple-choice test, recount facts or statistics, recall a process, rules, definitions; quote law or procedure); 'key words' - verbs which describe the activity to be trained or measured at each level (arrange, define, describe, label, list, memories, recognise, relate, reproduce, select, state). Level 2 or category (Comprehension); behaviour descriptions (understand meaning, re-state data in one's own words, interpret, extrapolate, translate); examples of activity to be trained, or demonstration and evidence to be measured (explain or interpret meaning from a given scenario or statement, suggest 
treatment, reaction or solution to given problem, create examples or metaphors); 'key words' - verbs which describe the activity to be trained or measured at each level (explain, reiterate, reword, critique, classify, summaries, illustrate, translate, review, report, discuss, re-write, estimate, interpret, theories, paraphrase, reference, example). Level 3 or category (Application); behaviour descriptions (use or apply knowledge, put theory into practice, use knowledge in response to real circumstances); examples of activity to be trained, or demonstration and evidence to be measured (put a theory into practical effect, demonstrate, solve a problem, manage an activity); 'key words' - verbs which describe the activity to be trained or measured at each level (use, apply, discover, manage, execute, solve, produce, implement, construct, change, prepare, conduct, perform, react, respond, role-play). Level 4 or category (Analysis); behaviour descriptions (interpret elements, organizational principles, structure, construction, internal relationships; quality, reliability of individual components); examples of activity to be trained, or demonstration and evidence to be measured (identify constituent parts and functions of a process or concept, or deconstruct a methodology or process, making qualitative assessment of elements, relationships, values and effects; measure requirements or needs); 'key words' - verbs which describe the activity to be trained or measured at each level (analyse, break down, catalogue, compare, quantify, measure, test, examine, experiment, relate, graph, diagram, plot, extrapolate, value, divide). Level 5 or category (Synthesis/create/build); behaviour descriptions (develop new unique structures, systems, models, approaches, ideas; creative thinking, operations); examples of activity to be trained, or demonstration and evidence to be measured (develop plans or procedures, design solutions, integrate methods, resources, ideas, parts; create teams or new approaches, write protocols or contingencies); 'key words' - verbs which describe the activity to be trained or measured at each level (develop, plan, build, create, design, organise, revise, formulate, propose, establish, assemble, integrate, re-arrange, modify). Level 5 or category (Evaluation); behaviour descriptions (assess effectiveness of whole concepts, in relation to values, outputs, efficacy, viability; critical thinking, strategic comparison and review; judgement relating to external criteria); examples of activity to be trained, or demonstration and evidence to be measured (review strategic options or plans in terms of efficacy, return on investment or cost-effectiveness, practicability; assess sustainability; perform a SWOT analysis in relation to alternatives; produce a financial justification for a proposition or venture, calculate the effects of a plan or strategy; perform a detailed in risk analysis with recommendations and justifications); 'key words' - verbs which describe the activity to be trained or measured at each level (review, justify, assess, present a case for, defend, report on, investigate, direct, appraise, argue, project-manage).

Cognitive teaching is intended as a learning process that forms the cognitive abilities of learners, with experimentation teaching techniques, and teaches an understanding of concepts and principles, as well as the relationships that exist between concepts. The intended student understanding arranged by plan. Substantively, this article directed to be a part of political education, especially to improve student's understanding of pillars of national and state life issues, and education intended to train critical, open, and rational thinking.

In order to understanding student learning, the teacher must be focusing on a range of approaches and contexts, planning teaching and learning through curriculum design and development, teaching it in the specific discipline. The LP gave the treatment by focusing to the any topic or issues of the SEdu. The subject matter discuss the political education including the culture values (Pancasila Ideology and Unity in Diversity) and the structure (the 1945 Indonesia Constitution and United State of Republic of Indonesia). The discussion on Pancasila Ideology is limited to understanding and memorizing the five precepts. The understanding of the people to the money in everyday life achieved in short time related to the materialism and pragmatism. The term of materialism is derived from the word the matter, or physical interchangeably, explaining behaviour as a form of mental image of a material or a physical thing's thinking, the think about the matter, about material objects [2]. The pragmatism is derived from the word pragmatic, have meaning 'practice' and 'practical' [1,14].

The discussion on Unity in Diversity is limited to the understanding of the symbol of the eagle, the writing of the slogan, and the understanding of meaning, and its application in heterogeneous life among groups. The discussion on the 1945 Indonesian Constitution is limited to the understanding of the article that regulates the rights of every citizen, and of article 33 (Earth and water and natural resources contained therein are controlled by the state and must be fought for great prosperity of the people), and its implementation [15]. The understanding of so dominant materialism that undermines all the joints of life, that all that is pursued in life is its estuary or ultimately money. The discussion on the United States of the Republic of Indonesia is limited to the understanding of the control of the islands in the territory of the Unitary State of the Republic of Indonesia by foreign parties, in particular concerning: earth, water and air for the interests of the livelihood of the people, which can threaten the sovereignty of the unitary state. The Indonesian people must respect for the symbol of the country, in the form of flags, Indonesia Raya songs, and heads of state.

The strength of materialism and pragmatism unfortunately followed by the decreasing the level of understanding of the student on the State Ideological issues. What the interesting thing in this article, however, the great onslaught of the influence of pragmatism and materialism on the younger generation (students) in Indonesia. However, educational institutions in higher education [16] who act as socialization agents (through the process of learning the four pillars of national life and state in the class, admittedly still proved to be a strong fortress to save them from the negative influences that it caused.

The relevant researches support the ideas. Cantoni [17] found the significant effect of the new curriculum on the shaping of the youth's ideology and social transformation. Related to the dominant ideology, Marx said that the superstructure of society, the realm of ideology, grows out of the base, the realm of production, to reflect the interests of the ruling class and justify the status quo that keeps them in power 
[18]. Gramsci stated that school not the neutral educational institutions, but to be cultural hegemony. It teach ideas, beliefs, values, and even identities that reflect the interests of the ruling class, and produce compliant and obedient members of society that serve the interests of that class [19].

The role of cognitive ability in explaining the level of change in the classroom, but not yet identify interactions as additive treatment effects as many parameters are changed simultaneously in the design [20].

The research problem is the process of learning in the classroom in the course of Sociology of Education can improve student's understanding on the four pillars of national and state life? How much the learning process in the classroom can improve student's understanding of that issues?

The aim of research is to explain the influence of the Learning Process (LP) on the level of the understanding of the student on the State Ideological (LUSSI) issues.

\section{METHOD}

The Level of Student Understanding evaluated by evaluative study, implemented by CIPP model [21,22]. Context (class), Input (Curriculum, Learning Plan, student understanding of the issues), mode of process of the teaching it issues (one way teaching, two way teaching or discus, task and formative test), product or output of the it issues (summative test). Evaluate study based on quasi experiment logic [23]. Pre test [24] implemented in order to measure the Context and Input that related to the student understanding about the issues. Treatment implemented how to processing the issues at the one-way teaching, two way teaching or discus, task and formative test. Impact measured [25] from the product or output of the issues (summative test). Cause and effect depend partly on each other and on the causal relationship in which both are embedded. That which produces any simple or complex idea, we denote by the general name cause and that which is produced effect. A cause that which makes any other thing, either simple idea, substance begin to be; and an effect is that, which had its beginning from some other thing. The three key ideas are: cause - effect, and cause relationship. In order to seek the better illuminate how quasi-experiments work, we measure the treatment. The impact of the treatment (learning process) on the level of the understanding of the student on the State Ideological issues can be shown in table 1.

TABLE I. THE IMPACT OF THE TREATMENT ON THE LEVEL OF THE STUDENT'S UNDERSTANDING ON THE STATE IDEOLOGICAL ISSUES.

\begin{tabular}{|c|c|c|c|}
\hline & \multicolumn{2}{|c|}{$\begin{array}{c}\text { Treatment } \\
\text { learning process) }\end{array}$} \\
\hline & & Intensive & Less intensive \\
\hline \multirow[t]{2}{*}{$\begin{array}{c}\text { Impact } \\
\text { (understanding) }\end{array}$} & Strong & $\begin{array}{l}1 \\
\text { Expected plan }\end{array}$ & $\begin{array}{l}2 \\
\text { Un-predicted } \\
\text { External factor }\end{array}$ \\
\hline & weak & $\begin{array}{l}3 \\
\text { Un-predicted } \\
\text { External factor }\end{array}$ & $\begin{array}{l}4 \\
\text { Predicted-un } \\
\text { plan }\end{array}$ \\
\hline
\end{tabular}

The quadrant 1 and 2, as the quadrant where the treatment (learning process), have the strong impact. But in quadrant 3 and 4 , the treatment can be shown a weak impact. Meanwhile the quadrant 1 and 3 , as the quadrant where the treatment (learning process) gave intensified. But quadrant 2 and 4 where the treatment gave less intensified. Considering the quadrant 1 and 4 we can predict it before the treatment gave. In the quadrant 1 can be shown as the expected impact or output, because teacher planned before and given intensive treatment. But in the quadrant 4 , can predict it before the treatment are given, because without plan, only have weak impact or output.

In quadrant 1 , can be seen the influence of the intensive learning process on the strong understanding of the student on the State Ideological issues. If there is more intensive treatment, so there is the more significant effect on the understanding of the student on the State Ideological issues. And is less intensive treatment, so there is the less effect on the understanding of the student on the State Ideological issues (quadrant 4). But in quadrant 2, can be seen that the influence of the less intensive treatment toward strong impact on the student's understanding on it issues, so we need time to explore what is happen. In quadrant 3 , can be seen the influence of the intensive treatment toward the weak of student's understanding on it issues. The external factors can be explored why the intensive treatment have weak impact on student's understanding, might be come from the interaction, instrumentation, history, or maturation effect.

\section{RESULT AND DISCUSSION}

Through the process of learning in the classroom in the course of Sociology of Education has indeed been able to improve student's understanding on the four pillars of national and state life. But in fact the process of learning in the classroom can only increase the student's understanding on the issue $(59 \%)$, still at the same level (34\%), even decreased (7\%). In order to increase the student's understanding on the issue by (59\%), actually expected in the treatment given, even if the value is not enough. What appeals to those whose understanding is the same level $(34 \%)$, the method might be revised or intensified. Even the decrease (7\%) occurs due to the saturation of the material that has actually been given at the previous level, or they assume that the Pancasila course is a component of the general compulsory subject in the education system in Indonesia. It is just an "additional" course (hidden curriculum) from the core courses in the course of study. While those who are not intensive follow the lectures that increase the understanding of the 4 pillar issues, it is thought to occur due to the large external factor $(41 \%)$ which indirectly affects the increasing level of student understanding, mainly due to interaction factor (there is interaction effect with other students during the experiment done which have been difficult to control it. It might be they have obtained the substance of Unity in Diversity, the 1945 Indonesia Constitution and United State of Republic of Indonesia Indonesian Political System, Political Sociology, Citizenship, Socio-Cultural System of Indonesia and Pancasila - at the previous level, or have obtained the material on extra-curricular activities related to leadership, and others that have not been disclosed in the quasi experiment. 


\section{CONCLUSIONS}

The learning treatment given in the course of Sociology of Education has been able to improve student's understanding on the four pillars of national and state life. Although the quasi experiment treatment capable increase the majority student understanding on the issue, but also found still at the same level, even decreased. Cause of the researcher fail to considerate interactional factor in this study. The first, the student not intensive follow the overall lectures. The second, they have obtained the substance of the pillar in another lecture - at the previous level. The fourth, they have obtained the extracurricular activities related to the four pillars.

\section{ACKNOWLEDGEMENTS}

Thank you to the Ministry of Research and Technology, Higher Education of the Republic of Indonesia who has provided funding support for this Postgraduate Team Research, including the funding to cover presentations activities on Annual Civic Education Conference (ACEC) 2018 in Bandung.

\section{REFERENCES}

[1] Webb, James L. Pragmatism(s) Plural: From Classical Pragmatism to Neo-Pragmatism, Journal of Economic Issues, 46:1, 45-74. 2012.

[2] Moser, Paul K and J.D. Trout. Contemporary materialism: a reader. New York: Routledge. 1995.

[3] Haryono, B., Model of four nation pillars Participatory Education for national integration. Community Journal 5 (2): 240-251. 2013.

[4] Haryono, B., The shifted idealism toward pragmatism and materialism in social exchange at marriage celebration in Surakarta City. Joint symposium Sebelas Maret University and Asian-Japan Research Center, Japan: Kokushikan University. 2017.

[5] Kansil, C. S. T. Pancasila dan Undang-Undang Dasar 1945 (Vol. 1). Pradnya Paramita. 2003.

[6] Maarif, A. S., Bhinneka Tunggal Ika Pesan Mpu Tantular Untuk Keindonesiaan Kita. Makalah dalam Lokakarya Empat Pilar Kehidupan Berbangsa dan Bernegara, Jakarta: MPR RI, 17-19. 2011

[7] Rahardjo, I. T. K., and Sudarso, S., Bung Karno, Islam, Pancasila, NKRI. Komunitas Nasionalis Religius Indonesia. 2006.

[8] Pateman, C., Political culture, political structure and political change. British Journal of Political Science, 1(3), 291-305. 1971

[9] Bourdieu, P., and Passeron, J. C., Reproduction in education, society and culture (Vol. 4). Sage. 1990

[10] Janoski, Thomas, Robert R. Alford, Alexander M. Hicks, and Mildred A. Schwartz. Handbook of Political Sociology: states, civil societies, and globalization. United States of America: Cambridge University Press. 2005 .

[11] Giroux, H. Theories of reproduction and resistance in the new sociology of education: A critical analysis. Harvard educational review, 53(3), 257-293. 1983.

[12] Mugahed, Waleed Al-Rahmi and Akram M. Zeki. A model of using social media for collaborative learning to enhance learners' performance on learning, Journal of King Saud University - Computer and Information Sciences 29, 526-535. 2017.

[13] Anderson, W. Orin and Krathwohl. R. D. A Taxonomy for Learning, Teaching, and Assessing: A revision of Bloom's Taxonomy of Educational Objectives. New York: Addison Wesley Longman, Inc. 2001.

[14] Wright, J. Pragmatism: Philosophical Aspects, International Encyclopedia of the Social and Behavioral Sciences, 2nd edition (2015) Vol 18. 2015
[15] Basuki, Udiyo, Qou Vadis 1945 Indonesia Constitution, Law supremacy journal, Vol. 1, June1, 2012.

[16] Becher, T., and Kogan, M. (1992). Process and structure in higher education (Vol. 10). Routledge.

[17] Cantoni, D., Chen, Y., Yang, D. Y., Yuchtman, N., and Zhang, Y. J. Curriculum and ideology. Journal of Political Economy, 125(2), 338392. 2017.

[18] Horkheimer, M., Critical theory New York, NY: Continuum. 1982. p. 188

[19] Lears, T. J., The concept of cultural hegemony: Problems and possibilities. The American Historical Review, 567-593. 1985

[20] Heckman, J., and Vytlacil, E., Identifying the role of cognitive ability in explaining the level of and change in the return to schooling. Review of Economics and Statistics, 83(1), 1-12. 2001.

[21] Scriven, Madaus G. M. and D. L. Stufflebeam. Evaluation Models, Boston: Kluwer-Nijhoff Publishing. 1985.

[22] Kellog, W. K. Foundation. Evaluation Handbook: Philosophy and Expectations, USA: Collateral Management Company. 1998.

[23] Cook, T. D., and Campbell, D. T., Quasi-experimentation: Design and analysis issues for field settings. Boston: Houghton Mifflin. 1979.

[24] Dimitrov, Dimiter M. and Phillip D. Rumrill, Jr. Pretest-posttest designs and measurement of Change. Work 20 159-165 159. 2003.

[25] Gertler, Paul J, Impact evaluation in practice. Washington DC: World Bank. 2011 